\title{
Optimization of Lavender (Lavandula angustifolia) Callus Culture
}

\section{Fatemeh Keykha, Azade Khadem ${ }^{1 *}$, Abdolreza Bagheri' ${ }^{1}$, Ahmad Sharifi and Maryam Ameri²}

\author{
Department Ornamental Plant Biotechnology, Iranian Academic Center for Education, \\ Culture and Research, Branch of Mashhad, Mashhad, Iran
}

Key words: Lavender (Lavandula angustifolia), Optimization, Callus culture, Light conditions, Explant sources

Lavender (Lavandula angustifolia) contains many valuable medicinal components such as linalool and linalyl acetate. This plant species is considered as one of the most important medicinal plants in the world. Enhancement of secondary metabolites production can be achieved through cell culture and genetic. In this study, the results of eight hormonal treatments, carried out with two types of explants under two light conditions were investigated. Maximum callus percentage, both in terms of fresh and dry weight were achieved from leaf explants on MS supplemented with $2 \mathrm{mg} / \mathrm{l}$ 2,4-D and $2 \mathrm{mg} / \mathrm{l} \mathrm{BAP}$ and grown in the dark.

Besides genetical properties, the production of plant metabolites, depends on many environmental factors that can affect both quality and quantity of pharmaceuticals. Nowadays, plant tissue culture is known as an efficient alternative method for conventional cultivations that may causes an increase in pharmaceutical metabolites (Stafford 1991, Keykha and Bagheri. 2013). Among various in vitro techniques, callus culture has been successfully established to produce herbal medicines (Kintzios et al. 2003). Dedifferentiation of plant cells can affect the amount of secondary metabolites production in some medicinal species and extraction of these substances from calli has been done in great extent (Patan et al. 2007, Bodhipadma et al. 2012). In addition, callus production is a necessity for cell suspension culture and also this undifferen-tiated cell mass

*Author for correspondence: <akh_agri69@yahoo.com>. 1Department of Biotechnology and Plant Breeding, College of Agriculture, Ferdowsi University of Mashhad, Mashhad, Iran. ${ }^{2}$ Researcher of Industrial Microorganisms Biotechnology Department, Iranian Academic Center for Education, Culture and Research, Branch of Mashhad, Mashhad, Iran. 
is widely used in gene transformation, metabolic pathway manipulation and biosynthetic pathway detection especially in medicinal plants. Lavender (Lavandula angustifolia) is one the most important medicinal plant species that the production of its secondary metabolites through tissue culture has also been considered (Bona et al. 2012, Parkash and Singh 2013). Lavender essential oil consists of 60 chemical compounds including linalool, linalyl acetate, 1,8-cineol, burneol, terpene-4-1 and camphor (Da Porto et al. 2009). The oil of this plant is known as a sedative and is widely used in depression treatment (Uehleke et al. 2012). The oil of Lavender is also manufactured with the name of Silexan and its antidepressant activity is assumed to be equivalent to the chemical medicine, Lorazepam (Woelk and Schlafke 2010). This plant species is also used as a pain reliefer, antifungal and anti-bacterial substance and is used in the treatment of burns and insect bites (Cavanagh and Wilkinson 2002). Due to the medicinal importance of this plant species, the present study was carried out to optimize callus induction and development conditions, in order to provide useful offers for further investigations to increase the efficiency of essential oil production.

Ten-15 cm shoots of Lavenders in the complete vegetative growth stage were isolated. To disinfect, the shoots were first washed under running water for $30 \mathrm{~min}$, then immersed in $70 \%$ ethanol for one min thereafter they were treated with $1 \%$ sodium hypochlorite for $20 \mathrm{~min}$ and finally were washed with sterile distilled water three times under a laminar flow cabinet. One $\mathrm{cm}$ long pieces of leaves and stems of sterile shoots were used as explants. Explants were cultured on MS with $30 \mathrm{~g} / \mathrm{l}$ sucrose and $8 \mathrm{~g} / \mathrm{l}$ agar. The investigated media consisted of IAA and 2,4-D $2 \mathrm{mg} / \mathrm{l}$ and $\mathrm{Kn}$ and BAP with 1 and $2 \mathrm{mg} / \mathrm{l}$, respectively to induce callus and were transferred to a growth room at $25 \pm 1^{\circ} \mathrm{C}$ and diverse light conditions (including darkness and lightness with $30 \mu \mathrm{m} / \mathrm{m}^{2} \mathrm{~s}$ light intensity). For a better growth, the induced calli were transferred every three weeks to fresh medium fortified with the same hormonal combinations and light regime. After two months of culture, several parameters such as percentage and the rate of callus growth, its fresh and dry weight, and color were noted. The methods used here were as follows: Callus percentage: total amount of explants containing callus/total amounts of explants in each treatment. Rate of callus: the rate of callus production every sevven days through a two-month culture.

Rate of callus: amount of explants containing callus $\times 7$ (days) + amount of explants containing callus $\times 14$ (days) $+\ldots+$ amount of explants containing callus $\times 56$ (days) / total amounts of explants containing callus.

Fresh and dry weight: isolating calli from cell suspension culture using filter paper and measuring their weight in order to obtain callus fresh weight, and 
after that placing calli in oven at $70^{\circ} \mathrm{C}$ for $24 \mathrm{hrs}$ and measuring their weight in order to obtain their dry weight.

Analysis of data was done by using of MSTAT-C software. For normal distribution, percentage data were converted using first angle conversion (Arcsine) prior to analysis of data.

There was a significant difference between the treatments in callus percentage $(p \leq 0.05)$. In all treatments, callus production in leaf explants were the same or more than stem explants which were suggested the effect of plant tissue on callus production. In the Mederos-Molina experiment (2004) in Salvia canariensis plant, callus induction in petiole explant was significantly more than stem, in all treatments used. Also the type of auxin was effective on callus induction, so that 2,4-D in comparison to IAA had a significant increase in callus percentage in both types of explants. Using the BAP in comparison to $\mathrm{Kn}$ had an increase in callus production so that $2 \mathrm{mg} / \mathrm{l}$ of 2,4-D with $2 \mathrm{mg} / \mathrm{l}$ of BAP induced callus in all leaf explants. Light conditions were ineffective in obtaining the highest callus percentage that have been seen in leaf explant, so that callus production in best treatment of leaf explant in both darkness and lightness conditions was 100\% (Fig. 1); however, Bona et al (2012) indicated that light treatment was significant for callus induction in L. angustifolia so that the explants that were transferred to dark conditions in their experiment did not produce any callus.

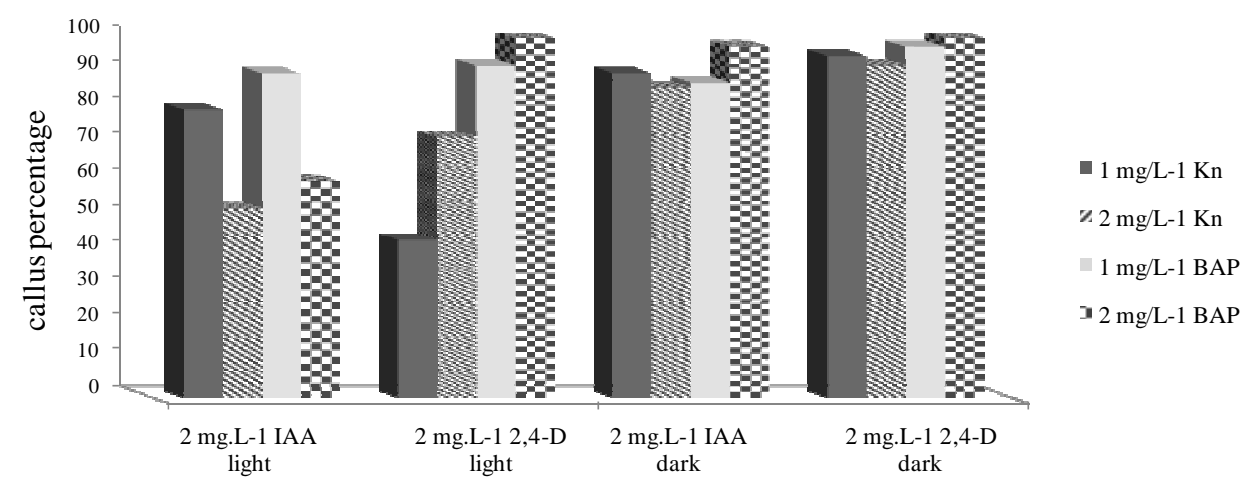

Fig. 1. The effect of light conditions and hormonal treatments on callus percentage in leaf explants.

Investigated rate of the callus in 50 days were indicated that the type of explant was effective on rate of callus production, so that the highest rate of callus production was obtained from leaf explants on media containing $2 \mathrm{mg} / \mathrm{l}$ 2,4-D and $1 \mathrm{mg} / \mathrm{l} \mathrm{Kn}$ which was estimated 34.65. So, application of 2,4-D was 
more effective in callus production. Also comparison between light conditions was indicated that the explants grown in lightness conditions had a more rate of callus production in comparison to darkness conditions (Table 1).

In all treatments, the extent of callus growth in leaf explants were significantly more than stem derived explants, so that the highest fresh and dry callus weight was 2.158 and $0.1535 \mathrm{~g}$, respectively. The significant increase in leaf calli weight in comparison to stem ones was indicated that the type of plant tissue was effective in detection of the best callus growth conditions in this plant. In previous studies, the type of used explant was proposed as an aspect effecting callus growth in different medicinal species (Thomas and Maseena 2006, Keykha and Bagheri 2013). In addition to the type of explant, different hormonal treatments also caused differences in the callus fresh and dry weight. 2,4-D 2 $\mathrm{mg} / \mathrm{l}$ produced the highest callus. Type and concentration of the cytokinin hormone also was effective on obtaining the highest fresh and dry calli weight, so that in presence of 2,4-D, the use of BAP with $2 \mathrm{mg} / \mathrm{l}$ in comparison to other hormone treatments caused a significant increase in the fresh and dry weight of the induced calli. Despite the effect of the explant type and used hormonal treatments on growth of induced calli, there was no significant difference between the explants in different light conditions in study. However there are many reports on visible effects of different light conditions on callus production of medicinal species of the Lamiaceae. For example Bernard et al. (2007) suggested that darkness condition was more effective in growth of Zataria multiflora Boiss calli.

Induced calli were different in color (brown, brownish-green, brownishcream and cream) and tissue conditions (soft and compact). Although there were differences in produced calli color in leaf and stem explants, but the production proportion of cream and brown calli were equal in both explants in estimated treatments and were 43.75 and $37.5 \%$ of the total induced calli in each explant, respectively. These results indicated that the type of explant did not have an effect on calli color. Despite the type of plant tissue, the treatment of explant with various hormonal compounds had a different result in the color of the calli production, so that all the explants treated with 2,4-D were produced a cream or brownish-cream color while the brownish calli were produced on mediums containing IAA. Lim et al. (2009) investigated callus production in Ocimum sanctum and reported the type of auxin was the most important factor in the induced calli color. Light conditions were effective on the color differences in induced calli, so that in lightness conditions, the amount of produced cream color calli were less than brown calli and were equivalent to 25 per cent of the total produced calli, but in the dark, $62.5 \%$ of the explants, produced cream calli 


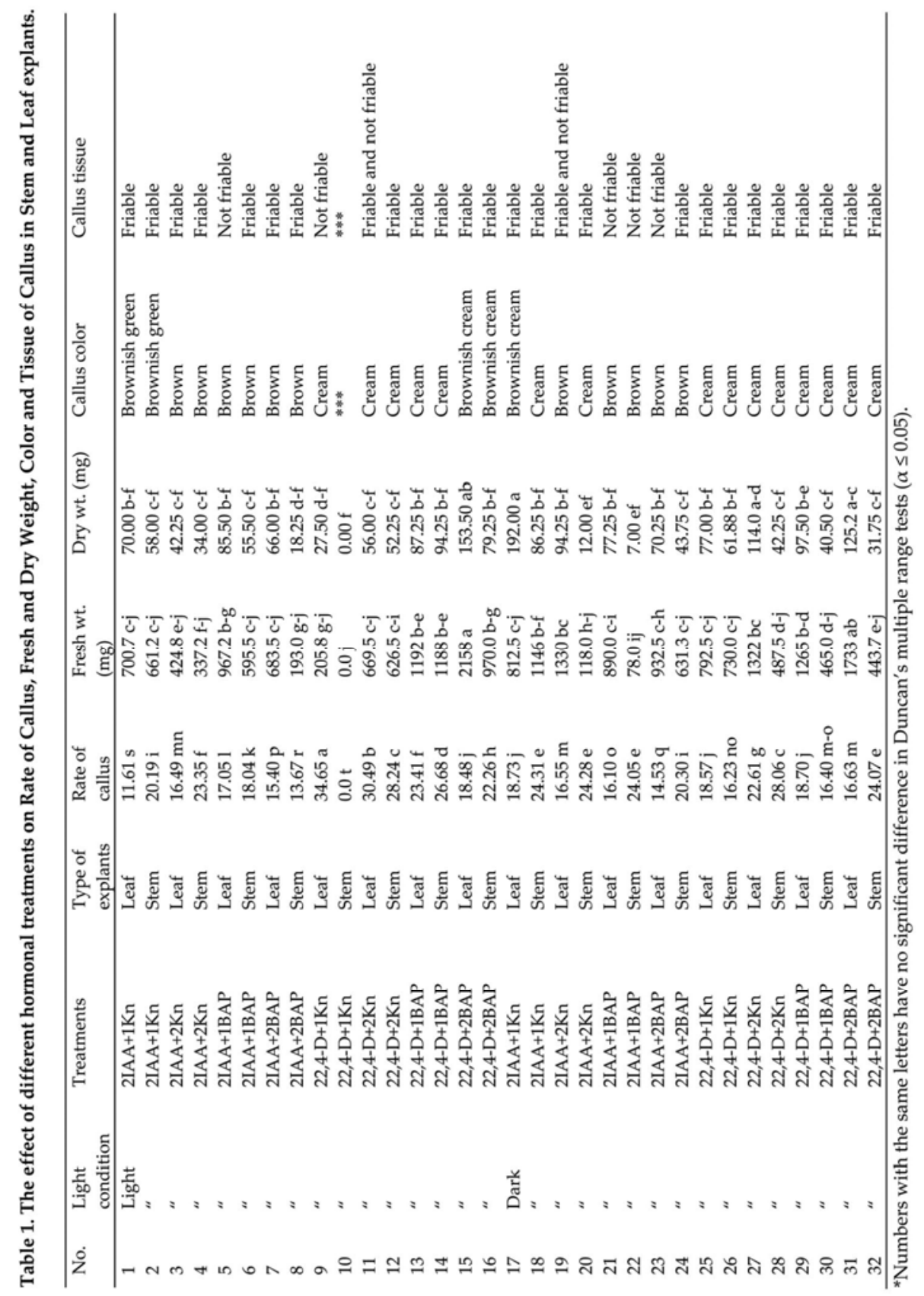


that were twice the amount of brown colored calli generated in the dark. The color of callus can be used as an indicator of a qualitative trait for future studies. The color of callus had a strong affinity with the other characters investigated. The calli were cream and was less affected by environmental factors. The calli with compact tissue were mainly brown and was obtained in the medium containing $2 \mathrm{mg} / \mathrm{l} \mathrm{IAA}$ and $1 \mathrm{mg} / \mathrm{l} \mathrm{BAP}$. Investigation into the qualitative aspects of calli showed that an addition of $2 \mathrm{mg} / \mathrm{l}$ IAA and BAP especially in lower concentrations had a negative effect on the quality of induced calli.

Investigation of different environmental conditions on callus induction and the properties of induced calli in Lavender indicated that the treatment of leaf explants with $2 \mathrm{mg} / \mathrm{l}$ 2,4-D and $2 \mathrm{mg} / \mathrm{l}$ BAP in dark conditions, was the most suitable treatment for the callus induction and its growth.

\section{Acknowledgments}

This research was supported by the Iranian Academic Center for Education, Culture and Research, Branch of Mashhad, Mashhad, Iran.

\section{Reference}

Bernard F, Shaker H, Hassanpoor H and NejadFallah, Z (2007) Growth optimization of Zataria multiflora Boiss tissue cultures and rosmarinic acid production improvement. Pak. J. Biol. Sci. 10: 3395-3399.

Bodhipadma K, Noichinda S, Phromthara T, Rutatip S and Nathalang K (2012) Determination of antioxidants from lemon basil callus during induction. J. Appl. Sci. 11: $1-8$.

Bona CM, Santos GD and Biasi LA (2012) Lavandula calli induction, growth curve and cell suspension formation. Revista Brasileira de Ciências Agrarias. 7: 17- 23.

Cavanagh HMA and Wilkinson JM (2002) Biological activities of lavender essential oil. Phytotherapy Res. 16: 301-308.

Da Porto C, Decorti D and Kikic I (2009) Flavour compounds of Lavandula angustifolia L. to use in food manufacturing: Comparison of three different extraction methods. Food Chemistry 112: 1072-1078.

Kintzios S, Makri O, Panagiotopoulos E and Scapeti (2003) In vitro rosmarinic acid accumulation in sweet basil (Ocimum basilicum L.). Biotechnology Letters. 25: 405-408.

KeykhaAkhar F, and Bagheri A (2013) The effect of hormonal composition, type of explant and light condition on callus production in periwinkle (Catharanthus roseus L.). Plant Tiss. Cult. \& Biotechnol. 23(1): 107-113.

Lim ZX, Kiong Ling AP and Hussein S (2009) Callus induction of Ocimum sanctum and estimation of its total flavonoids content. Asian J. Agril. Sci. 1: 55-61.

Mederos-Molina S (2004) In vitro callus induction and plants from stem and petiole explants of Salvia canariensis L. Plant Tiss. Cult. 14: 167-172. 
Parkash V and Singh H (2013) Lavandula angustifolia L. (lavender): An important aromatic medicinal shrub and its in vitro micro-propagation for conservation. J. Agril, Technol. 9: 701-712.

Patan AK, Dreger M, Paukstza MG, Mscisz A, Mielcarek S, Baraniak M, Buchwald w, Marecik R, Grajek W and Mrozikiwicz PM (2007) Salvia milthiorrhiza Bunge in vitro cultivation in callus cultures. Nerva Polinica. 53: 88-96.

Stafford A (1991) The manufacture of food ingredients using plant cell and tissue cultures. Trends in Food Sci. and Technol. 2: 116-122.

Thomas TD and Maseena EA (2006) Callus induction and plant regeneration in Cardiospermum halicacabum Linn. an important medicinal plant. Scientia Horticulturae 108: 332-336.

Uehleke B, Schaper S, Dienel A, Schlaefke S and Stange R (2012) PhaseII trial on the effects of Silexan in patients with neurasthenia, post-traumatic stress disorder or somatization disorder. Phytomedicine 19: 665-671.

Woelk H and Schlafke S (2010) A multi-center, double-blind, randomised study of the lavender oil preparation Silexan in comparison to Lorazepam for generalized anxiety disorder. Phytomedicine 17: 94-99. 